\title{
Ecommerce Strategy Towards Shopee Consumer Behaviour In Online Shopping Through Electronic Word Of Mouth (EWOM) Variables
}

\author{
I Gusti Made Oka Astana1* \\ ${ }^{1}$ Sekolah Tinggi Ilmu Ekonomi Satya Dharma, Singaraja, Indonesia
}

\section{ART ICLE INFO}

\section{Article history:}

Received September 02, 202

Revised September 03, 2021

Accepted October 20, 2021

Available online November 25, 2021

Keywords:

Online Shopping, Consumer Behaviour, E-commerce Strategy, EWOM

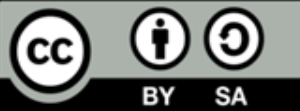

This is an open access article under the CC BY-SA license.

Copyright $(2021$ by Author. Published by Universitas Pendidikan Ganesha.

\begin{abstract}
A B S T R A C T
The growing use of internet-based technologies provides enterprise Ecommerce with transformative benefits. The success of E-commerce is determined by the behavior of sellers and their decisions about which platform to use between application-based E-commerce or social media. Online shopping through the internet supports consumers to find information about a product or service and make purchases through direct interaction with online retailers. Word of mouth plays an essential role in consumer behavior, especially in online marketing, which supports consumers seeking more references. This study aims to analyze the effect of E-commerce and electronic word of mouth (EWOM) on consumer behavior in online shopping. The study was conducted on 75 respondents, and researchers used SmartPLS 3.0 to examine the relationship between variables in the model through SEM. From the research results obtained, internet marketing strategies directly affect EWOM and consumer behavior, while EWOM also directly affects consumer behavior. E-commerce startups have the most significant direct positive influence on online shopping consumer behavior across all channels. This result means that Shopee should give prime attention to its E-commerce strategy to increase its consumers.
\end{abstract}

\section{INTRODUCTION}

The use of the internet in meeting daily needs is now common throughout the world. This is supported by the rapid development of technology, especially in the field of information and communication (Bakirtaș \& Akkaș, 2020; Kaplan et al., 2021; Wang, 2020). The advantages in terms of time efficiency and cost become one of the main reasons why the world community prefers the internet (Artati et al., 2016; Laksana, 2020; Tempola et al., 2020). One of the fields that is very utilizing the rapid development of the internet is the business world, where Ecommerce and online shopping began to dominate. Ecommerce is a digital environment that allows commercial transactions to take place between many organizations and individuals (G. Liu, 2022; Mao et al., 2021; Nissen \& Krampe, 2021). Many companies are currently introducing products that they sell over the internet. The use of burgeoning internet-based technology provides enterprise Ecommerce with transformative benefits, for example, real-time customer service, dynamic pricing, personalized offerings, or enhanced interactions (Akter \& W., 2016; Diwanji \& Cortese, 2020). While commercial transactions in Indonesia involve the exchange of value, for example money, across organizational or individual boundaries in return for goods and services. The success of Ecommerce is determined by the behaviour of sellers and their decisions about which platforms to use between appbased Ecommerce or social media. Then the form of Ecommerce that sellers choose to influence consumer behaviour can be divided into three. The first is B2C (Bussiness to Customer), which is electronic commerce involving retail products and services to individual buyers. The second is B2B (Bussiness to Bussiness), which is electronic commerce involving sellers of goods and services between business people. The last is C2C (Customer to Customer), which is electronic commerce involving consumers who sell directly to consumers (Garín-Muñoz et al., 2019).

One of the manufacturers or online stores that have entered to market their products through the internet is Shopee which has the name of the website www.Shopee.co.id. Shopee is also called by the name Shopee Indonesia or Shopee.co.id (Miftahul et al., 2020; Wulan et al., 2019). Shopee is like an online mall. Shopee was established as an Ecommerce website in 2009 and was only launched in 2015. Shopee was the 
most popular Ecommerce website in Indonesia in 2015 (Karina, 2019; Lestari et al., 2021). According to Alexa data, by the end of 2020 Lazada is ranked 426th in the world rankings for the popular website category. As well as being ranked 24th in Indonesia as the most visited website in Indonesia.

Judging from the existing data, it can be concluded that Shopee Ecommerce is the most popular Ecommerce in Sukasada village. The decision to use what Ecommerce to shop online is certainly carefully thought out by consumers. In the Pandemic Period, Shopee continues to exist in its field. Good enough reassessment (review) affects its existence in Sukasada Village in particular. The occurrence of fluctuations in purchases and transaction activities in each month due to the existence of several promotions or tempting offers that are often held by some Ecommerce, not spared also with Shopee which often relied on Free Postage. One example is the 12th month of December, with harbolnas (National Online Shopping Day) where there are many interesting offers such as free postage and discounts. In March when precisely the start of the Covid-19 Pandemic, there was a decrease in purchases due to a decrease in people's purchasing power due to the weak economy during the Pandemic. But again up in the next month because most people are more comfortable to shop through online, just wait at home. The study of consumer behaviour centres on the way individuals make decisions to leverage their available power summers (time, money, effort) to buy consumer-related goods (Francis \& Sarangi, 2022; Xu et al., 2022). Consumer behaviour is the act that directly engages in the acquisition, consumption, and end of products/services, including the processes that precede and follow action (Cruz-Cárdenas et al., 2019; Vemula et al., 2021). Consumer behaviour is the study of the units and decision-making processes involved in the acceptance, use and purchase, and determination of goods, services and ideas. From some understanding of these experts it can be concluded that consumer behaviour is the action taken by consumers to achieve and meet their needs both to use, and spend goods and services, including the decision process that proceeds and the decisions that follow. Word of mouth is the primary informal communication channel of consumers (Lis \& Neßler, 2014; Soliana \& Pratomo, 2016). This influences the short-term and long-term decisions of consumers to buy a product. Thus, Word of mouth plays an important role in consumer behaviour, let alone in online marketing that allows consumers to search for more references.

e-WOM is a positive or negative statement made by a potential consumer, real consumer, or former consumer about a product or company that can be accessed by many people or institutions over the internet (Aynie et al., 2021; Filieri et al., 2021; H. Liu et al., 2021). In the study, the integration of traditional WOM motifs with the characteristics contained in EWOM. Internet use has changed the way consumers communicate and share opinions or reviews about products or services that have been consumed. The process of communication between consumers over the internet is known as Electronic Word of Mouth (EWOM). EWOM defines a medium of communication to share information about a product or service that has been consumed between consumers who do not know each other and meet before. EWOM has an influence on consumer behaviour before a consumer decides to buy a product or service (Donthu et al., 2021; Jimenez \& Mendoza, 2013; Zhou et al., 2021).

e-WOM into three dimensions that is intensity (Goyette et al., 2010). Intensity in e-WOM is the number of opinions written by consumers on a social networking site. Divide the indicators of Intensity as follows: Frequency of accessing information from social networking sites, Frequency of interaction with users of social networking sites, and The number of reviews written by users of social networking sites (Goyette et al., 2010). The second dimensions is Valence of Opinion, it is the consumer's opinion either positive or negative about the product, service and brand. Valence of Opinion has two properties: negative and positive. Valence of Opinion includes: Positive comments from users of social networking sites, and Recommendations from social deterrent site users. Dimensions content is the last dimensions e-WOM, it is the content of information from social networking sites related to products and services. Indicators of content include: Food and beverage variety information, Information on the quality (taste, texture and temperature) of food and drink, and Information about the price offered. Electronic Word of Mouth is considered to be an evolution of traditional face-to-face communication to become more modern with the help of cyberspace, or an electronic medium in computer networks that is widely used for one-way communication purposes and online reciprocity (Jalivand \& Samiei, 2012). Electronic Word of Mouth is a venue or a very important place for consumers to give their opinions and is considered more effective than WOM because of its wider level of accessibility and reach than traditional offline WOM. This research aims to find out how Ecommerce and electronic word of mouth (EWOM) affect consumer behaviour in shopping online.

\section{METHODS}

The technique used to collect data is a questionnaire. This study used consumer respondents from Shopee domiciled in Sukasada Village Buleleng Regency who spent from January to December 2020 which 
amounted to 75 people. Data collection uses questionnaires with a likert scale of 1 to 10 . Data is processed with SEM analysis techniques using smartPLS 3.0 application.

\section{RESULTS AND DISCUSSIONS}

\section{Results}

In the outer model validity test there are two factors that will be observed in the validity test, namely the value of loading factor (convergent validity) and cross loading value (discriminant validity). Convergent validity measures the correlation between question items and constructs in research. An individual reflexive measure is said to correlate if it is more than 0.7 with the construct to be measured. However, for early stage research of the development of the scale measurement of the loading factor value of 0.6 is considered sufficient (Ghozali, 2013). In the early stages of data testing find out the accuracy of indicators in explaining exogenous constructs on models using loading factors. Based on the following research model path diagram, shown the results as in Figure 1.

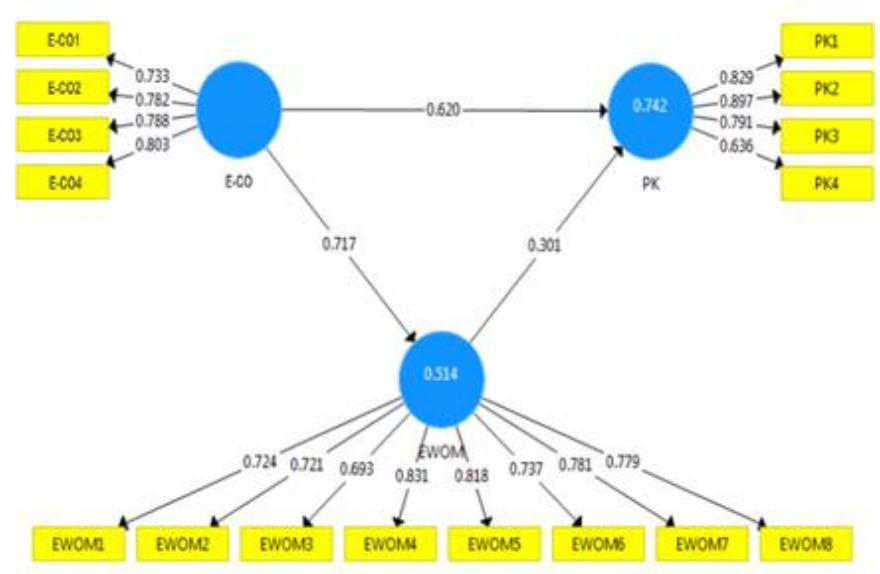

Figure 1. Loading Factor Value

Based on the image above, the loading factor value shows results that have met convergent validity because all loading factors $>0.6$. Thus, it can be concluded that convergent validity of all constructs is valid. To reinforce the valid statements of the construct, researchers also used the Average Variance Extracted (AVE) method (Sugiyono, 2017). Good construct required that the AVE value should be above 0.50. Based on the results of data analysis, the AVE value to the entire variable above $>0.50$ which states that the construct values of all variables are qualified or said to be valid.

Table 1. Value of Composite Realiability dan Cronbach Alpha

\begin{tabular}{lcccc}
\hline & $\begin{array}{c}\text { Cronbach's } \\
\text { Alpha }\end{array}$ & rho_A & $\begin{array}{c}\text { Composite } \\
\text { Reliability }\end{array}$ & $\begin{array}{c}\text { Average Variance Extracted } \\
\text { (AVE) }\end{array}$ \\
\hline EWOM & 0.896 & 0.892 & 0.917 & 0.508 \\
PK & 0.802 & 0.909 & 0.871 & 0.631 \\
E-Co & 0.781 & 0.903 & 0.859 & 0.604 \\
\hline
\end{tabular}

Table 1 shows that all constructs in the study yielded composite reliability values above $>0.70$ and cronbach's alpha value above $>0.60$. The lowest composite reliability and cronbach's alpha values were on the SIM construct with values of 0.859 and 0.781 . So it can be concluded that all the constructs of this study are reliable. The R-square value for the EWOM variable obtained by 0.514 , and for the PK variable obtained by 0.742 . The significance of the estimated parameters provides very useful information regarding the relationships between research variables. The basis used in testing relationships is the value found in the output result of the inner weight. In PLS testing statistically every relationship is performed with simulation. In this case the bootstrapping method is done to the sample. Bootstrap testing is also intended to minimize the problem of innormality of research data. Here are the test results with the bootstrapping method using SmartPLS in Table 2. 
Table 2. Path Coefficients

\begin{tabular}{lccccc}
\hline & $\begin{array}{c}\text { Original } \\
\text { Sample } \\
\text { (0) }\end{array}$ & $\begin{array}{c}\text { Sample } \\
\text { Mean } \\
\text { (M) }\end{array}$ & $\begin{array}{c}\text { Standard } \\
\text { Deviation } \\
\text { (STDEV) }\end{array}$ & $\begin{array}{c}\text { T Statistics } \\
(|\mathbf{O} / \mathbf{S T D E V}|)\end{array}$ & P Values \\
\hline EWOM -> PK & 0.301 & 0.318 & 0.110 & 2.738 & \\
E-Co -> EWOM & 0.717 & 0.733 & 0.053 & 13.506 & 0.006 \\
E-Co -> PK & 0.620 & 0.605 & 0.100 & 6.222 & 0.000 \\
\hline
\end{tabular}

Source: SmartPLS Output Results 2.0

Table 4 shows the results of the relationship test between variables where the Ecommerce Strategy (SIM) positively affects Consumer Behaviour (PK) with a paramenter coefficient value of $(0.620)$ then the Ecommerce Strategy (SIM) variable has a positive effect on EWOM with a paramenter coefficient value of (0.717) while EWOM has a positive effect on Consumer Behaviour (PK) with a coefficient value of $(0.301)$. All three variables have a calculated $t$ value greater than the table $t$ (1.96). So it can be concluded that variables have a valid relationship.

\section{Discussion}

Based on the results of the analysis that has been explained, it can be seen that the influence of Shopee's Internet Marketing Strategy on Consumer Behaviour is significant where the result coefficient is 0.620 with a statistical value greater than 1.96 which is 6,222 . Thus demonstrating that a good Internet Marketing Strategy have a good impact on Shopee's Consumer Behaviour. This means that the better the Ecommerce strategy, the more consumer behaviour to shop online from Shopee. When viewed from the value of outer loading the four dimensions of Ecommerce, it can be said that the Ecommerce environment dimension is the dimension with the highest value (Akter \& W., 2016; G. Liu, 2022; Nissen \& Krampe, 2021). This means that the Ecommerce environment dimension is the most powerful dimension for measuring Ecommerce variables (Garín-Muñoz et al., 2019; Kong et al., 2020). Based on the results of the analysis that has been explained, it can be seen that the influence of the Internet Marketing Strategy on EWOM Shopee is a significant positive where the coefficient result is 0.717 with a statistical value greater than 1.96 which is 13,506 . Thus showing that a good Ecommerce state have a good impact on EWOM. This means that the better the Ecommerce strategy, the more electronic word of mouth or word of mouth conversation through cyberspace (Bigdellou et al., 2022; Lis \& Neßler, 2014; Soliana \& Pratomo, 2016). When viewed from the value of outer loading the four dimensions of Ecommerce, it can be said that the Ecommerce environment dimension is the dimension with the highest value. This means that the Ecommerce environment dimension is the most powerful dimension for measuring Ecommerce variables (Diwanji \& Cortese, 2020; Mao et al., 2021).

Based on the results of the analysis that has been explained, it can be seen that the influence of EWOM on Consumer Behaviour shopee is a significant positive where the result coefficient of 0.301 with a statistical value greater than 1.96 is 2,738. Thus demonstrating that a good EWOM will have a good impact on Consumer Behaviour. This means that the more word-of-mouth conversations through the internet (ewom) the higher one's online shopping behaviour will be (Bigdellou et al., 2022; Donthu et al., 2021). When viewed from the outer loading value of the three dimensions of the ewom, it can be said that the content dimension is the dimension with the highest value. This means that the content dimension is the most powerful dimension for measuring ewom variables, or in other words the content of word of mouth conversations over the internet is the most important thing. Research entitled "Electronic Word Of Mouth (E-Wom), Consumer Satisfaction And Direct and Indirect Influence on Consumer Buying Interest (Feb Untag Student Study In Semarang)", obtained results that showed there was a significant positive influence of eword of mouth and consumer satisfaction on social media, there was a positive influence of consumer satisfaction on e-word of mouth, and there is a direct and indirect influence of eword of mouth on consumer buying interests (Lis \& Neßler, 2014). Social networking can open up opportunities for promotional media quickly effectively and efficiently. While in this study, internet marketing strategies directly affect EWOM and consumer behavior, while EWOM also directly affects consumer behavior.

\section{CONCLUSION}

Ecommerce start-ups have the greatest direct positive influence on the behaviour of online shopping consumers of all channels. These results mean that Shopee should pay primary attention to its Ecommerce strategy to increase its consumers. Based on the conclusions of the study above, suggestions that need to be followed up, both for knowledge development, for further researchers, especially those 
interested in the field of Marketing Management who want to study consumer behaviour, as well as practical interests.

\section{REFERENCES}

Akter, S., \& W., S. F. (2016). Big Data Analytics in E-commerce: a Systematic Review and Agenda for Future Research. Electron Markets, 26(2), 173-194. https://doi.org/10.1007/s12525-016-0219-0.

Artati, Y., Tumirah, \& Suparmo. (2016). Hubungan Antara Pemanfaatan Internet Sebagai Sumber Belajar Dengan Prestasi Belajar Mahasiswa Semester III Prodi Diii Kebidanan Sutomo Surabaya. SAINTEKBU, 3(1). https://doi.org/10.32764/saintekbu.v3i1.43.

Aynie, R. Q., Hurriyati, R., \& Dirgantari, P. D. (2021). Strategi pemasaran electronic word of mouth pada ecommerce dalam menghadapi era digital 4.0 di indonesia Electronic word of mouth marketing strategy on e-commerce in facing the digital era. Inovasi, 17(1), 136-143. https://doi.org/10.29264/jinv.v17i1.8483.

Bakirtaş, H., \& Akkaş, C. (2020). Technology Readiness And Technology Acceptance Of Academic Staffs. International Journal of Management Economics and Business, 16(4). https://doi.org/10.17130/ijmeb.853629.

Bigdellou, S., Aslani, S., \& Modarres, M. (2022). Optimal promotion planning for a product launch in the presence of word-of-mouth. Journal of Retailing and Consumer Services, 64. https://doi.org/10.1016/j.jretconser.2021.102821.

Cruz-Cárdenas, J., Zabelina, E., Guadalupe-Lanas, J., Palacio-Fierro, A., \& Ramos-Galarza, C. (2019). COVID19, consumer behavior, technology, and society: A literature review and bibliometric analysis. $\begin{array}{lllll}\text { Technological Forecasting } & \text { Shd }\end{array}$ https://doi.org/10.1016/j.techfore.2021.121179.

Diwanji, V. S., \& Cortese, J. (2020). Contrasting user generated videos versus brand generated videos in ecommerce. Journal of Retailing and Consumer Services, 54. https://doi.org/10.1016/j.jretconser.2019.102024.

Donthu, N., Kumar, S., Pandey, N., Pandey, N., \& Mishra, A. (2021). Mapping the electronic word-of-mouth (eWOM) research: A systematic review and bibliometric analysis. Journal of Business Research, 135. https://doi.org/10.1016/j.jbusres.2021.07.015.

Filieri, R., Lin, Z., Pino, G., Alguezaui, S., \& Inversini, A. (2021). The role of visual cues in eWOM on consumers' behavioral intention and decisions. Journal of Business Research, 135. https://doi.org/10.1016/j.jbusres.2021.06.055.

Francis, A., \& Sarangi, G. K. (2022). Sustainable consumer behaviour of Indian millennials: Some evidence. Current Research in Environmental Sustainability, 4. https://doi.org/10.1016/j.crsust.2021.100109.

Garín-Muñoz, T., López, R., Pérez-Amaral, T., Herguera, I., \& Valarezo, A. (2019). Models for individual adoption of eCommerce, eBanking and eGovernment in Spain. Telecommunications Policy, 43(1). https://doi.org/10.1016/j.telpol.2018.01.002.

Ghozali, I. (2013). Aplikasi Analisis Multivariate dengan Program IBM SPSS 21 Update PLS Regresi. Badan Penerbit Universitas Diponogoro.

Goyette, I., Ricard, I., Bergeron, J., \& Marticotte, F. (2010). EWOM Scale: Wordof-Mouth Measurement Scale for e-Services Context. Canadian Journal of Administrative Sciences, 27(1), 5-23. https://doi.org/10.1002/cjas.129.

Jalivand, M. R., \& Samiei, N. (2012). The Effect of Electronic Word of Mouth on Brand image and Purchase Intention: An empirical study in the automobile industry in Iran. Marketing Intelligence \& Planning, 30(4). https: //doi.org/10.1108/02634501211231946.

Jimenez, F. R., \& Mendoza, N. A. (2013). Too Popular to Ignore: The Influence of Online Reviews on Purchase Intentions of Search and Experience Products. Journal of Interactive Marketing, 23(3), 226-235. https://doi.org/10.1016/j.intmar.2013.04.004.

Kaplan, L. R., Farooque, M., Sarewitz, D., \& Tomblin, D. (2021). Designing Participatory Technology Assessments: A Reflexive Method for Advancing the Public Role in Science Policy Decision-making. Technological Forecasting and Social 171. https://doi.org/10.1016/j.techfore.2021.120974.

Karina, M. (2019). Pengaruh E-servicescape Online Marketplace Shopee pada Perceived Value dan Kepuasan Pelanggan, serta Dampaknya terhadap Loyalitas Pelanggan. Jurnal Maksipreneur: Manajemen, Koperasi, Dan Entrepreneurship, 9(1). https://doi.org/10.30588/jmp.v9i1.534. 
Kong, X. T. R., Yang, X., Peng, K. L., \& Li, C. Z. (2020). Cyber physical system-enabled synchronization mechanism for pick-and-sort ecommerce order fulfilment. Computers in Industry, 118. https://doi.org//10.1016/j.compind.2020.103220.

Laksana, D. N. L. (2020). Implementation of Online Learning in The Pandemic Covid-19: Student Perception in Areas with Minimum Internet Access. Journal of Education Technology, 4(4), 509-509. https://doi.org/10.23887/jet.v4i4.29314.

Lestari, S., Handayani, N. U., \& Mahacandra, M. (2021). The Influence Of Using Shopeepay And Shopee Paylater Features On Shopee User Purchasing Decisions During The Covid- 19. Jurnal Teknik Industri, 16(4). https://doi.org/10.14710/jati.16.4.242-248.

Lis, B., \& Neßler, C. (2014). Electronic Word Of Mouth (E-Wom), Consumer Satisfaction And Direct and Indirect Influence on Consumer Buying Interest (Feb Untag Student Study In Semarang). Business and Information Systems Engineering, 6(1), 63-65. https://doi.org/10.1007/s12599-013-0306-0.

Liu, G. (2022). An ecommerce recommendation algorithm based on link prediction. Alexandria Engineering Journal, 61(1). https://doi.org/10.1016/j.aej.2021.04.081.

Liu, H., Jayawardhena, C., Osburg, V.-S., Yoganathan, V., \& Cartwright, S. (2021). Social sharing of consumption emotion in electronic word of mouth (eWOM): A cross-media perspective. Journal of Business Research, 132. https://doi.org/10.1016/j.jbusres.2021.04.030.

Mao, M., Chen, S., Zhang, F., Han, J., \& Xiao, Q. (2021). Hybrid ecommerce recommendation model incorporating product taxonomy and folksonomy. Knowledge-Based Systems, 214. https: //doi.org/10.1016/j.knosys.2020.106720.

Miftahul, A., Endro, S. J., \& Rizal, I. R. (2020). Multi-Criteria Decision Making with the VIKOR and SMARTER Methods for Optimal Seller Selection from Several E-Marketplaces. E3S Web of Conferences, 202. https://doi.org/10.1051/e3sconf/202020214002.

Nissen, A., \& Krampe, C. (2021). Why he buys it and she doesn't - Exploring self-reported and neural gender differences in the perception of eCommerce websites. Computers in Human Behavior, 121. https://doi.org/10.1016/j.chb.2021.106809.

Soliana, \& Pratomo. (2016). Antaseden dari Word Of Mouth. Jurnal Ekonomi, 7(1), 1-8. https://doi.org/10.47007/jeko.v7i01.1515.

Sugiyono. (2017). Statistika Untuk Penelitian. Alfabeta.

Tempola, F., Muhammad, M., \& Mubarak, A. (2020). Penggunaan Internet Dikalangan Siswa SD di Kota Ternate: Suatu Survey, Penerapan Algoritma Clustering dan Validasi DBI. Jurnal Teknologi Informasi Dan Ilmu Komputer, 7(6). https://doi.org/10.25126/jtiik.2020722370.

Vemula, H. L., Khichi, T., Murugesan, G., Valderrama-Plasencia, L., Salazar-Gonzales, M., \& Ventayen, R. J. M. (2021). ROLE of cloud computing and its impact on consumer behavior in financial sector. Materials Today: Proceedings, 3. https://doi.org/10.1016/j.matpr.2021.11.146.

Wang, Y. H. (2020). Design-based research on integrating learning technology tools into higher education classes to achieve active learning. Computers and Education, 156(May), 103935. https://doi.org/10.1016/j.compedu.2020.103935.

Wulan, W. N. N., Suharyati, \& Rosali. (2019). Analisis Pembelian Tidak Terencana pada Toko Online Shopee. Ekonomi Dan Bisnis, 6(1). https://doi.org/10.35590/jeb.v6i1.830.

$\mathrm{Xu}$, J., Du, H. S., Shen, K. N., \& Zhang, D. (2022). How gamification drives consumer citizenship behaviour: The role of perceived gamification affordances. International Journal of Information Management, 64. https://doi.org/10.1016/j.ijinfomgt.2022.102477.

Zhou, S., Barnes, L., McCormick, H., \& Cano, M. B. (2021). Social media influencers' narrative strategies to create eWOM: A theoretical contribution. International Journal of Information Management, 59. https://doi.org/10.1016/j.ijinfomgt.2020.102293. 